\title{
Influence of Travel Distance and the Season upon Transport-Induced Mortality in Fattened Cattle
}

\author{
M. MALENA ${ }^{2}$, E. VOSLÁŘOVÁ ${ }^{1}$, P. TOMANOVÁ ${ }^{1}$, R. LEPKOVÁ ${ }^{1}$, I. BEDÁŇOVÁ ${ }^{1}, V$. VEČEREK ${ }^{1}$ \\ ${ }^{1}$ University of Veterinary and Pharmaceutical Sciences, Czech Republic \\ ${ }^{2}$ State Veterinary Administration, Czech Republic \\ Received May 10, 2006 \\ Accepted September 5, 2006
}

\begin{abstract}
Malena M., E. Voslářová, P. Tomanová, R. Lepková, I. Bedáňová, V. Večerek: Influence of Travel Distance and the Season upon Transport-Induced Mortality in Fattened Cattle. Acta Vet Brno 2006, 75: 619-624.

Animal welfare during the transport of fattened cattle has a significant effect on the likelihood of mortality or poor meat quality. The number of animals that died during transport to a slaughterhouse or briefly after being delivered to a slaughterhouse may serve as an indicator of animal welfare during transport. The aim of this study was to determine the mortality in fattened cattle resulting from transport to a slaughterhouse, and to examine the effect of both travel distance and the season of the year on the mortality rate in fattened cattle during transport.

The mortality rate in fattened cattle during transport to a slaughterhouse that were monitored in the Czech Republic in the period of 1997 - 2004 was $0.007 \% \pm 0.003 \%$. However, it varied significantly $(p<0.05, \mathrm{r}=0.90)$ with the travel distance to a slaughterhouse, ranging from $0.004 \%$ $\pm 0.002 \%$ at a travel distance up to $50 \mathrm{~km}$ to $0.024 \% \pm 0.027 \%$ at a travel distance over $300 \mathrm{~km}$.

The season of the year also had a significant impact on the mortality rate in transported fattened cattle. In general, the highest mortality rate was observed in summer months (particularly in July and August) and winter months (particularly in January and February). Correlation $(r=0.68)$ was proved $(p<0.01)$ between the mortality rate in fattened cattle and ambient temperature.

The results indicate relatively low sensitivity of fattened cattle to stress during transport, which was reflected in transport-induced mortality. The increasing travel distance and the transport of cattle in summer or winter months resulted in an increase in transport-induced mortality rates.
\end{abstract}

Cattle, mortality, welfare, stress, travel distance, summer months, winter months

Animal welfare during the transport of fattened cattle has a significant effect on the likelihood of mortality or poor meat quality. The observance of animal welfare requirements during transport to a slaughterhouse reduces the stress in transported animals. Failure to observe welfare conditions during the transport of animals increases stress in animals before slaughter in a slaughterhouse and may lead to increased mortality during transport. The number of animals that died during transport or briefly after the transport has ended could serve as an indicator of failure to comply with the respective requirements of animal welfare during the transport of animals.

The level of animal welfare during the transport of cattle to a slaughterhouse with regards to stress in transported animals was studied by a number of experts. Fazio and Ferlazzo (2003) claim that the reaction of animals to stressors depends on the duration and intensity of these stressors. Maria et al. (2004) studied the scoring system for evaluating the stress to cattle of commercial loading and unloading. Von Holleben et al. (2003) followed the handling of slaughter cattle on journeys in Germany. Marahrens et al. (2003) addressed the issue of the long-distance road transport of cattle.

Tadich et al. (2000) focused on selected blood variables as indicators of stress during transport by road up to 36 hours. They determined increase in the blood concentrations of cortisol, glucose and CK activity from the farm to arrival at the abattoir and stunning.

Address for correspondence:

Ing. Eva Voslářová, Ph.D.

University of Veterinary and Pharmaceutical Sciences Brno

Palackého 1-3, 61242 Brno

Czech Republic

\author{
Tel.: +420 541562773 \\ Fax: +420 541562790 \\ E-mail: voslarovae@vfu.cz \\ http://www.vfu.cz/acta-vet/actavet.htm
}


Similarly, B rad shaw et al. (1996ab) found increased plasma concentrations of cortisol and beta- endorphin in pigs immediately after loading. Broom et al. (1996) investigated the physiological effects of road transport on sheep. Loading and the start of driving produced increases in the heart rate, and cortisol and prolactin concentrations; whereas osmolality and haematocrit decreased. The impact of transport-induced stress on the selected cellular response indicators in cattle was studied by Wernicki et al. (2003).

The conditions of transport influence the welfare of cattle during transport. They also affect the incidence rates of transport-induced immobility in cattle, injuries in carcass, the impaired quality of both carcass and meat. The incidence of immobility in cattle caused by unsuitable handling practices during transport to a slaughterhouse was reported by Pišstěková et al. (2004). Chandra and Das (2001) recorded the occurrence of bruising in buffaloes that was caused by handling practices and short-haul road transportation. Mechanical damage to animals during transport and the development of processes resulting from the exposure of animals to stressors may be reflected in veterinary decisions regarding the edibility of meat and may result in non-edible meat, as the sensory properties of such meat may deviate from normal, as reported by Večerek et al. (2003). Gallo et al. (2000) studied the transport of steers focusing on the effects of transport time before slaughter on behaviour and carcass characteristics. The impact of transportinduced stress on meat quality in cattle was studied by Honkavaara et al. (2003). Villarroel et al. (2003a) estimated the effect of commercial transport in Spain on cattle welfare and meat quality.

As reported by Hartung et al. (2003), the stressful transport produces a negative effect on meat quality. Bulls, steers and heifers react differently to transport, and therefore transport schemes should be adapted to the different needs of the animals. Villarroel et al. (2003b) and Maria et al. (2003) also studied the effect of transport time on the sensory quality aspects of beef meat. Transport time had a significant effect on meat tenderness and overall liking. Gallo et al. (2001) examined the effect of 36 hour road transport on some quality indicators of beef meat and concluded that such transport negatively affected the quality of produced meat and that rest stops along these journeys improved aspects such as less fallen animals, less bruising and less dark cutters.

Wikner et al. (2003b) studied the factors which affected stress in cattle during transport. In light of the behavioural analysis, they particularly point out to driving performance, handling during loading and unloading and air quality in the vehicle. Wikner et al. (2003a) estimated the effect of various climatic conditions, stocking density on transport times from the perspective of transport-induced stress in cattle. According to Costa et al. (2003) environmental conditions also represent one of the stress factors affecting the behaviour of bulls during road transport. Von Holleben et al. (2003) consider the following factors stressful: regrouping, loading, transport time, loading density, mounting prevention, unloading and lairage time. Noise and vehicular motion as potential stressors during the transport of sheep were studied by Hall et al. (1998).

The aim of this study was to determine the mortality rate in cattle during transport to a slaughterhouse in the Czech Republic in the period of 1997 - 2004, and to examine the effect of both travel distance and the season of the year (individual months) on the mortality rate in cattle during transport to a slaughterhouse.

\section{Materials and Methods}

In the period of 1997 - 2004, the inspectors of the State Veterinary Administration of the Czech Republic recorded the numbers of fattened cattle (fattened bulls and heifers) transported to a slaughterhouse for normal slaughter. The transport-induced mortality rates were recorded, i.e. the number of dead animals in the transport vehicle and the number of animals that died upon transport. Only the data concerning the fattened cattle intended for slaughter in a slaughterhouse (bulls, heifers) were analysed. The transport of fattened cattle to emergency 
slaughter was not recorded because such cattle have impaired health and the respective mortality rate in this kind of cattle would be affected by current diseases and not by the transport to a slaughterhouse.

The effect of travel distance on the transport-induced mortality of fattened cattle was determined for several travel distances: up to $50 \mathrm{~km}$, from $51 \mathrm{~km}$ to $100 \mathrm{~km}$, from $101 \mathrm{~km}$ to $200 \mathrm{~km}$, from $201 \mathrm{~km}$ to $300 \mathrm{~km}$, and over $300 \mathrm{~km}$. The average annual rates in percentage were calculated for the above-mentioned travel distances.

The effect of the season of the year (individual months) on the mortality rate in fattened cattle during transport to a slaughterhouse was determined on the basis of the average numbers of dead animals in $\%$ for individual months of the monitored period.

The average monthly ambient temperatures at 07:00 $\mathrm{h}$ at two places typical of the road transport of animals were obtained (the Olomouc site and the Tuhán site) in cooperation with the Czech Meteorological Institute.

The results of absolute and relative frequencies, average values and standard deviations were processed using the programme Excel (using the module for statistical calculations). The Spearman's rank correlation test implemented in the programme Unistat 5.1 was used to evaluate the correlation between the number of dead animals and the travel distance, and the correlation between the number of dead animals and the average deviation of ambient temperature from the average annual temperature in individual months.

\section{Results}

Out of a total number of $1,844,757$ monitored animals transported to different slaughterhouses in the Czech Republic in the period from 1997 to 2004, 125 animals died.

The average annual mortality rates in fattened cattle and the effect of travel distance on the transport-induced mortality rate in fattened cattle are illustrated in Table 1.

Table 1. The dependence of the average annual transport-induced mortality rate in fattened cattle on the travel distance

\begin{tabular}{|l|c|c|c|c|c|c|}
\hline & \multicolumn{2}{|c|}{$\begin{array}{c}\text { Transported } \\
\text { (number) }\end{array}$} & \multicolumn{2}{c|}{$\begin{array}{c}\text { Deceased } \\
\text { (number) }\end{array}$} & \multicolumn{2}{c|}{$\begin{array}{c}\text { Mortality } \\
(\%)\end{array}$} \\
\hline Transport distance & mean & sd & mean & sd & mean & sd \\
\hline$<50 \mathrm{~km}$ & 147,469 & 31,859 & 5.1 & 3.1 & 0.004 & 0.002 \\
\hline 51 to $100 \mathrm{~km}$ & 45,559 & 3,542 & 3.3 & 2.0 & 0.007 & 0.004 \\
\hline 101 to $200 \mathrm{~km}$ & 24,995 & 1,627 & 4.9 & 3.0 & 0.019 & 0.012 \\
\hline 201 to $300 \mathrm{~km}$ & 9,350 & 2,680 & 1.6 & 1.8 & 0.018 & 0.025 \\
\hline$>300 \mathrm{~km}$ & 3,222 & 1,873 & 0.8 & 0.9 & 0.024 & 0.027 \\
\hline Total & 230,595 & 39,912 & 15.6 & 5.8 & 0.007 & 0.003 \\
\hline
\end{tabular}

Explanations:

mean $=$ mean annual value acquired in the period from 1997 to 2004

$\mathrm{sd}=$ standard deviation

It follows from Table 1 that transport-induced mortality in fattened cattle over the whole monitored period of time was $0.007 \% \pm 0.003 \%$. The effect of travel distance on the transport-induced mortality in fattened cattle was as follows: at a travel distance up to $50 \mathrm{~km}$ the mortality rate was $0.004 \% \pm 0.002 \%$, whereas at long travel distances over $300 \mathrm{~km}$ the mortality rate was substantially higher, reaching $0.024 \% \pm 0.027 \%$. The positive correlation $(\mathrm{r}=0.90)$ between the mortality rate in fattened cattle and the travel distance was significant $(p<0.05)$.

The effect of the season of the year (individual months) on the transport-induced mortality in fattened cattle is illustrated in Table 2.

It follows from Table 2 that the season of the year (individual months) has a major effect on the mortality rate in fattened cattle. Generally, the highest mortality rate was observed in summer months (particularly in July and August) and winter months (particularly in January and February). The positive correlation $(\mathrm{r}=0.68)$ between the mortality rate in fattened cattle and the deviation of transport temperature from the annual average temperature $\left(7.2^{\circ} \mathrm{C}\right)$ was highly significant $(p<0.01)$. 
Table 2. The average monthly transport-induced mortality rate in fattened cattle

\begin{tabular}{|c|c|c|c|c|c|c|c|c|}
\hline \multirow[b]{2}{*}{ Month } & \multicolumn{2}{|c|}{$\begin{array}{l}\text { Transported } \\
\text { (number) }\end{array}$} & \multicolumn{2}{|c|}{$\begin{array}{l}\text { Deceased } \\
\text { (number) }\end{array}$} & \multicolumn{2}{|c|}{$\begin{array}{c}\text { Mortality } \\
(\%)\end{array}$} & \multicolumn{2}{|c|}{$\begin{array}{c}\text { Ambient } \\
\text { temperature }\left({ }^{\circ} \mathrm{C}\right)\end{array}$} \\
\hline & mean & sd & mean & $\mathrm{sd}$ & mean & $\mathrm{sd}$ & mean & $\mathrm{d}$ \\
\hline January & 20,421 & 6,675 & 1.6 & 1.6 & 0.008 & 0.007 & -2.6 & 9.8 \\
\hline February & 17,126 & 3,352 & 2.0 & 2.0 & 0.012 & 0.013 & -0.8 & 8.0 \\
\hline March & 19,873 & 3,177 & 1.1 & 0.8 & 0.006 & 0.005 & 1.8 & 5.4 \\
\hline April & 19,763 & 3,517 & 1.0 & 1.3 & 0.005 & 0.007 & 6.6 & 0.6 \\
\hline May & 20,115 & 2,974 & 1.0 & 0.8 & 0.005 & 0.004 & 13.1 & 5.9 \\
\hline June & 19,215 & 4,500 & 1.3 & 1.3 & 0.006 & 0.006 & 15.8 & 8.6 \\
\hline July & 18,464 & 4,180 & 1.9 & 2.2 & 0.010 & 0.012 & 16.9 & 9.7 \\
\hline August & 17,926 & 2,807 & 1.6 & 0.9 & 0.010 & 0.007 & 16.6 & 9.4 \\
\hline September & 19,889 & 3,330 & 0.9 & 0.8 & 0.004 & 0.004 & 11.1 & 3.9 \\
\hline October & 20,770 & 3,825 & 1.3 & 1.3 & 0.006 & 0.006 & 6.9 & 0.3 \\
\hline November & 19,984 & 3,351 & 1.0 & 0.5 & 0.005 & 0.003 & 2.5 & 4.7 \\
\hline December & 17,049 & 3,630 & 1.0 & 1.1 & 0.006 & 0.006 & -1.3 & 8.5 \\
\hline
\end{tabular}

Explanations:

mean $=$ mean month value acquired for the given month in the period from 1997 to 2004

$\mathrm{sd}=$ standard deviation

$\mathrm{d}=$ deviation of the average monthly ambient temperature from average annual temperature $\left(7.2^{\circ} \mathrm{C}\right)$

\section{Discussion}

Wikner et al. (2003a) claim that transport by road can induce significant stress in cattle. Maria et al. (2004) report that the loading, transport, and unloading of cattle as part of transport to a slaughterhouse is very stressful for animals. According to von Holleben et al. (2003), Marahrens et al. (2003), Tadich et al. (2000) stress is manifested particularly by changes in behaviour, heart rate, cortisol levels, glucose levels, and creatine-kinase levels, and also by variation in cellular response indicators, as reported by Wernicki et al. (2003). Changes also occur in carcass bruising, as reported by Chandra and Das (2001), Gallo et al. (2000), Honkavaara et al. (2003).

High levels of stress in cattle may also be reflected in the transport-induced mortality. We found that the transport-induced mortality in fattened cattle was $0.007 \pm 0.003 \%$ which is relatively low, indicating substantially higher resistance of fattened cattle to transportinduced stress as compared with other animals, e.g. pigs, in whom the mortality rate during the transport to a slaughterhouse in the Czech Republic was $0.107 \pm 0.013 \%$, as reported by Večerek et al. (2006).

Fazio and Ferlazzo (2003) found that the reaction of animals to stressors depends on the duration and intensity of these stressors. We have found in our study that an increase in the mortality rate in fattened cattle associated with the increasing travel distance indicates that the long-time transport of fattened cattle increases the stress load in fattened cattle which results in increasing the transport-induced mortality rate in fattened cattle, ranging from $0.004 \pm 0.002 \%$ at a travel distance up to $50 \mathrm{~km}$ to $0.024 \pm 0.027 \%$ at longer travel distances (over $300 \mathrm{~km}$ ). Gallo et al. (2000, 2001), Honkavaara et al. (2003), Marahrens et al. (2003), Tadich et al. (2000), Villarroel et al. (2003ab) have revealed changes in the indicators of stress at the long-distance transport of cattle.

We have found increased mortality in fattened cattle not only in summer months but also in winter months. Increased mortality rates in summer and winter months are associated with external air temperature and air humidity during these months that have a negative effect on the welfare of fattened cattle during transport. These findings do not comply with the results found in pigs transported to a slaughterhouse where the mortality rate in summer months 
was higher, possibly as a result of ambient temperature exceeding $10^{\circ} \mathrm{C}$ ( W arris s 1998 ; Večerek 2006). Mortality in fattened cattle also increases when the ambient temperature during transport drops below $0{ }^{\circ} \mathrm{C}$. Villarroel et al. (2003a) point out to the finding that the variables indicated slightly more stressful conditions in winter than in summer.

The mortality rate in fattened cattle can be reduced when the requirements for transport are strictly observed. According to von Holleben et al. (2003), this particularly concerns the measures with regard to regrouping, loading, transport time, unloading, and lairage time to minimize transport-induced stress in fattened cattle. Wikner et al. (2003b) also points out to driving performance, handling during loading and unloading, air quality in the vehicle. Costa et al. (2003) emphasises temperature-humidity index. On the other hand, impaired conditions during transport will have a negative impact on the carcass of fattened cattle and the quality of meat from this cattle, as stated by Gallo et al. (2001), Hartung et al. (2003), Maria et al. (2003), Pištěková et al. (2004), Večerek et al. (2003), Villarroel (2003ab).

\section{Přepravní vzdálenost a roční období z pohledu úhynů vykrmovaného skotu při přepravě na porážku}

Welfare při přepravě vykrmovaného skotu má výrazný vliv na stresové zatížení zvířat. Ukazatelem úrovně welfare při přepravě zvírat mohou být počty uhynulých zvírat při přepravě a zvířat uhynulých na jatkách krátce po ukončení přepravy. Cílem práce bylo zjistit úroveň úhynů vykrmovaného skotu v souvislosti s přepravou na jatky, zjistit vliv přepravní vzdálenosti na úhyny vykrmovaného skotu a vliv ročního období na počty uhynulého vykrmovaného skotu.

V souvislosti s přepravou na jatky byly proto v České republice v období let 1997 až 2004 sledovány úhyny vykrmovaného skotu. Úroveň úhynů u vykrmovaného skotu byla zjištěna $0,007 \% \pm 0,003 \%$, avšak významně $(p<0,05, \mathrm{r}=0,90)$ se měnila v závislosti na přepravní vzdálenosti na jatky, a to z $0,004 \% \pm 0,002 \%$ při přepravě do $50 \mathrm{~km}$ až na $0,024 \% \pm 0,027 \%$ při přepravě nad $300 \mathrm{~km}$.

Také roční období mělo vliv na počty úhynů přepravovaného vykrmovaného skotu. Celkově $\mathrm{k}$ nejvyšším úhynům došlo $\mathrm{v}$ letních měsících, zejména $\mathrm{v}$ červenci a srpnu a v zimních měsících, zejména v lednu a únoru. Byla prokázána $(p<0,01)$ korelace úhynů vykrmovaného skotu a teploty prostředí $(\mathrm{r}=0,68)$.

Z výsledků vyplývá poměrně nízká citlivost vykrmovaného skotu na stresové zatížení způsobené přepravou na jatky projevující se úhyny v důsledku přepravy. Rostoucí přepravní vzdálenost a přeprava v letních měsících a zimních měsících se projevila zvýšeným počtem uhynulého vykrmovaného skotu v souvislosti s jeho přepravou na jatky.

\section{Acknowledgements}

Supported by the Research Project No MSM6215712402 Veterinary aspects of food safety and quality.

\section{References}

BRADSHAW RH, PARROTT RF, GOODE JA, LLOYD DM, RODWAY RG, BROOM DM 1996a: Behavioural and hormonal responses of pigs during transport: Effect of mixing and duration of journey. Anim Sci 62: 547-554

BRADSHAW RH, PARROTT RF, FORSLING ML, GOODE JA, LLOYD DM, RODWAY RG, BROOM DM 1996b: Stress and travel sickness in pigs: Effects of road transport on plasma concentrations of cortisol, betaendorphin and lysine vasopressin. Anim Sci 63: 507-516

BROOM DM, GOODE JA, HALL SJG, LLOYD DM, PARROTT RF 1996: Hormonal and physiological effects of a 15 hour road journey in sheep: Comparison with the responses to loading, handling and penning in the absence of transport. Br Vet J 152: 593-604

CHANDRA BS, DAS N 2001: The handling and short-haul transportation of spent buffaloes in relation to bruising and animal welfare. Trop Anim Health Prod 33: 155-163 
COSTA LN, LO FIEGO DP, CASSANELLI MG, TASSONE F, RUSSO V 2003: Effect of journey time and environmental condition on bull behaviour and beef quality during road transport in Nothern Italy. Dtsch Tierarztl Wochenschr 110: 107-110

FAZIO E, FERLAZZO A 2003: Evaluation of stress during transport. Vet Res Commun 27: 519-524

GALLO C, ESPINOZA MA, GASIC J 2001: Effects of 36 hours road transport with or without a resting period on live weight and some meat quality aspects in cattle. Arch Med Vet 33: 43-53

GALLO C, PEREZ S, SANHUEZA C, GASIC J 2000: Effects of transport time of steers before slaughter on behaviour, weight loss and some carcass characteristics. Arch Med Vet 32: 157-170

HALL SJG, KIRKPATRICK SM, LLOYD DM, BROOM DM 1998: Noise and vehicular motion as potential stressors during the transport of sheep. Anim Sci 67: 467-473

HARTUNG J, MARAHRENS M, VON HOLLEBEN K 2003: Recommendations for future development in cattle transport in Europe. Dtsch Tierarztl Wochenschr 110: 128-130

HONKAVAARA M, RINTASALO E, YLONEN J, PUDAS T 2003: Meat quality and transport stress of cattle. Dtsch Tierarztl Wochenschr 110: 125-128

MARAHRENS M, VON RICHTOFEN I, SCHMEIDDUCH S, HARTUNG J 2003: Special problems of longdistance road transport of cattle. Dtsch Tierarztl Wochenschr 110: 120-125

MARIA GA, VILLARROEL M, CHACON G, GEBRESENBET G 2004: Scoring system for evaluating the stress to cattle of commercial loading and unloading. Vet Rec 154: 818-821

MARIA GA, VILLARROEL M, SANUDO C, OLLETA JL, GEBRESENBET G 2003: Effect of transport time and ageing on aspects of beef quality. Meat Sci 65: 1335-1340

PIŠTĚKOVÁ V, OŠŤÁDALOVÁ I, SEDLÁKOVÁ J, TOMANOVÁ P, BEDÁŇOVÁ I 2004: Emergency slaughter of cattle due to immobility. Acta Vet Brno 73: 533-538

TADICH N, GALLO C, ALVARADO M 2000: Effects on cattle of transportation by road up to 36 hours with and without a rest on some blood variables indicator of stress. Arch Med Vet 32: 171-183

VEČEREK V, KOZÁK A, MALENA M, TREMLOVÁ B, CHLOUPEK P 2003: Veterinary meat inspection of bovine carcasses in the Czech Republic during the period of 1995 - 2002. Vet Med-Czech 48: 183-189

VEČEREK V, MALENA M., MALENA M jr., VOSLÁŘOVÁ E, CHLOUPEK P 2006: The impact of the transport distance and season on losses of fattened pigs during transport to the slaughterhouse in the Czech Republic in the period from 1997 to 2004 . Vet Med-Czech 51: 21-28

VILLARROEL M, MARIA GA, SANUDO C, GARCIA-BELENGUER S, CHACON G, GEBRESENBET G 2003a: Effect of commercial transport in Spain on cattle welfare and meat quality. Dtsch Tierarztl Wochenschr 110 : $105-107$

VILLARROEL M, MARIA GA, SANUDO C, OLLETA JL, GEBRESENBET G 2003b: Effect of transport time on sensorial aspects of beef meat quality. Meat Sci 65: 353-357

VON HOLLEBEN K, HENKE S, SCHMIDT T, BOSTELMANN N, VON WENZLAWOWICZ M, HARTUNG J 2003: Handling of slaughter cattle in pre and post transport situations including loading and unloading on journeys up to 8 hours in Germany. Dtsch Tierarztl Wochenschr 110: 93-99

WARRISS PD 1998: The welfare of slaughter pigs during transport. Animal Welf 7: 365-381

WERNICKI A, URBAN-CHMIEL R, MIKUCKI P, PUCHALSKI A, KANKOFER M 2003: Influence of transport stress on chosen cellular response parameters. Med Wet 59: 608-611

WIKNER I, GEBRESENBET G, NILSSON C 2003a: Assessment of air quality in a commercial cattle transport vehicle in Swedish summer and winter conditions. Dtsch Tierarztl Wochenschr 110: 100-104

WIKNER I, GEBRESENBET G, TOLO E 2003b: Dynamic performances of cattle transporting vehicle on Scandinavian roads and behavioural response of animals. Dtsch Tierarztl Wochenschr 110 : 114-120 